\title{
Stem Anatomy of Four Genera of Family Cucurbitaceae
}

\author{
Makesh Kumar ${ }^{1}$, B. Veni, P. ${ }^{1}$, Vijayalakshmi, M${ }^{1}$., Selvaraj, K. ${ }^{*}$, J. Stephan ${ }^{2}$ \\ ${ }^{1}$ Department of Botany, G. Venkataswamy Naidu College (Autonomous), Kovilaptti, India \\ ${ }^{2}$ Jawaharlal Nehru Tropical Botanic Garden and Research Inst., Palode, Thiruvananthapuram, Kerala, India \\ *Corresponding Author: Selvaraj, K, Department of Botany, G. Venkataswamy Naidu College \\ (Autonomous), Kovilaptti , India
}

\begin{abstract}
Stem anatomical characteristics of Coccinia grandis (L.) Voigt., Luffa acutangula (L.) Rox, Lagenaria siceraria (Molina) Standl and Cucurbita pepo L. belonging to the family Cucurbitaceae were studied at Department of Botany, G. Venkataswamy Naidu College (Autonomous), Kovilaptti. The specimens were collected from in and around Kovilpatti Taluk. The morphological characteristics and the internal structure of stem were studied in the four species. In stem anatomical character all species possesses bicollateral vascular bundles, number of vascular bundles (big and small) varies in each species. The morphological and anatomical characteristics of the four species are useful in identification of the plant.
\end{abstract}

Keywords: Diversity, Cucurbitaceae, Anatomy, Taxonomy.

\section{INTRODUCTION}

In the angiospermic taxa one of the important family is Cucurbitaceae. It comes under the order: Cucurbitales, class: Magnoliopsida. Cucurbitaceae family consists of two subfamilies and eight tribes.Two subfamilies are Cucurbitoideae and Zanonioideae. These tribes are Benincaseae, Cucurbiteae, Joliffieae, Melothrieae, Schizopeponeae, Sicyeae, Trichosantheae and Zanonieae [1]. Based on the ethic group of people the leaves, roots and fruits of this family been used as food and medicine in worldwide [2,3]. Plant anatomy deals with the analysis and alignment of the cells, tissues forming organs of plants. The internal anatomical features of the family cucubitaceae have played an increasingly important role in identifying phylogenetic relationships in many taxa [4]. In the economic point of view, it is more important plant families in the world [5].

The implication and scientific importance of several species of cucurbitaceae have been demonstrated by several authors. The morhphological anatomy of melon species of cucurbitaceae and their importance [6], tendrils and fruit stalk anatomy helps in identification of cucurbitas species in Nigeria [7], usage of plant in cucurbitaceae family with identifying their parts in earlier days [8] the seed coat anatomical study of cucutbitaceae plant species help in the identification of their intra and inter relationship among the families [9] and the systematic and taxonomic significance of the petiole and stem anatomy of Momordica species shows marked variation in identification and utilization of cucurbitas species [10].

The main aim of the present study is elucidating the morphological and anatomical characteristics of the four species, to compare the anatomical characters among the members of cucurbitaceae and to obtain the anatomical information that can be fulfil the need of systematic studies on the cucurbitaceae.

\section{MATERials AND MethodS}

The plant material used for the investigation were in the nearby agricultural at Newappaneri $\left(9.1943^{\circ}\right.$ $\mathrm{N}$ latitude, $77.8463^{\circ} \mathrm{E}$ longitude) on habitats located near the Kovilpatti Town. Two $15-\mathrm{cm}$ long twigs from aboveground and one 5-cm long piece of a stem were collected, dissected in approximately $3-\mathrm{cm}$ long pieces, and then fixed immediately in an ethanol and water mixture (1:1). Free hand sections were made to see the anatomical variations. 5 different accessions were selected for each species and 5 samples of each accession were taken for the study. Tissues were stained in $1 \%$ aqueous Safranin solution for 5 minutes, washed in distilled water and the parts were mounted in glycerin. The materials observed using the Optika Bionocular Microscope (Model B-353). 


\section{RESULT AND DISCUSSION}

\subsection{Morphological studies}

\subsubsection{Coccinia Grandis (L.) Voigt}

Coccinia grandis, the ivy gourd, also known as scarlet gourd, tindora and kowai fruit, is a tropical vine. It grows primarily in tropical climates and is commonly found in the southern Indian states, where it forms a part of the local cuisine. Coccinia grandis is cooked as a vegetable. This plant is a perennial climber with single tendrils and glabrous leaves. The leaves have 5 lobes and are $6.5-8.5 \mathrm{~cm}$ long and $7-8 \mathrm{~cm}$ wide. Female and male flowers emerge at the axils on the petiole, and have 3 stamens.

\subsubsection{Luffa Acutangula (L.) Roxb}

Ridged Sponge Gourd is a tropical running vine with rounded leaves and yellow flowers. Both female and male flowers appear on the same plant. Pollination is done by bees. Leaves are angled, but little if at all lobed except on young shoots. The leaves are covered with short hairs and the fruits are ribbed and cylindrical shaped. It has ten longitudinal angular ridges and a tapered neck. Ridged luffa is very similar to L. cylindrica which lacks the ridge. The length of the fruit is one to two feet.

\subsubsection{Lagenaria Siceraria (Molina) Standl.}

Vigorous annual herb. Stems prostrate or climbing, angular, ribbed, thick, brittle, softly hairy, up to $5 \mathrm{~m}$ long, cut stems exude no sap. Leaves simple, up to $400 \mathrm{~mm}$ long and $400 \mathrm{~mm}$ broad, shortly and softly hairy, broadly egg-, kidney- or heart-shaped in outline, undivided, angular or faintly 3-7-lobed, lobes rounded, margins shallowly toothed, crushed leaves non-aromatic. Leaf stalks up to $300 \mathrm{~mm}$ long, thick, often hollow, densely hairy, with two small, lateral glands inserted at the leaf base. Tendrils split in two.

\subsubsection{Cucurbita pepo $L$}

Cucurbita pepo is an annual, monoecious climber. The stems are fleshy, stout, setose and develop series of multifid tendrils. The leaves are simple. The petiole is stout, fleshy, setose and up to $10 \mathrm{~cm}$ long. The blade is triangular, $20-30 \mathrm{~cm}$ across, irregularly five-lobed, setose, cordate at base, dentate at base and acute at apex. The flowers are massive and solitary on a 2-20-cm-long, setose pedicel. The fruiting pedicel is robust and pentagonal. The fruit is a berry which has a multitude of shapes and colours according to the varieties. The seeds are ovoid, flattened, $1-1.5 \mathrm{~cm} \times 0.5-1 \mathrm{~cm}$, white and smooth.

\subsection{Anatomical Study}

The stem anatomical study of four species of cucurbitaceae was studied and their vascular bundle size, numbers were tabulated in the table: 1 and fig. 1.

Table1. Number and size of vascular bundle in stem

\begin{tabular}{|l|l|c|c|c|c|c|c|}
\hline S.No. & \multirow{2}{*}{ Plant Spp. } & \multicolumn{2}{|c|}{$\begin{array}{c}\text { No. of Vascular } \\
\text { bundles }\end{array}$} & \multicolumn{4}{|c|}{ Size of Vascular bundles } \\
\cline { 3 - 8 } & & Big & Small & $\begin{array}{c}\text { Big Ver } \\
\text { tical }(\boldsymbol{\mu m})\end{array}$ & $\begin{array}{c}\text { Big Horizo- } \\
\text { ntal }(\boldsymbol{\mu m})\end{array}$ & $\begin{array}{c}\text { Small Ver } \\
\text { tical }(\boldsymbol{\mu m})\end{array}$ & $\begin{array}{c}\text { Small Hori } \\
\text { zontal }(\boldsymbol{\mu m})\end{array}$ \\
\hline 1. & Coccinia grandis & 4 & 4 & 21 & 18 & 12 & 10 \\
\hline 2. & Luffa acutangula & 3 & 6 & 22 & 28 & 13 & 11 \\
\hline 3. & Langenaria siceraia & 5 & 5 & 21 & 20 & 14 & 15 \\
\hline 4. & Cucurbita pepo & 5 & 5 & 44 & 49 & 22 & 27 \\
\hline
\end{tabular}

In Coccinia grandis (L.) Voigt. the transverse section has oval shaped outline and easily distinguished into dermal, ground and vascular tissue system, single layered epidermis made up of oval to barrel shaped cells with the presence of trichomes. The ground tissue composed of cortex, endodermis, pericycle and pith, outer cortex contains 3-6 layered polygonal collenchymatous cells and inner cortex contains 3-8 layered polygonal parenchymatous cells. A single layered barrel shaped parenchymatous cells of endodermis is thin walled. Vascular bundles embedded in the ground tissues, four bundles each in two circle, open and bicollateral type. Parenchymatous oval or round shaped cells of bundle sheath present. 5-8 layered oval or irregular shaped Phloem cells are persent. Xylem 3- to 5- layered, the cells round or oval in shape. Pith is present

In Luffa acutangula (L.) Roxb. the transverse section has oval wavy shaped outline and distinguished into dermal, ground and vascular tissue system, single layered epidermis made up of barrel shaped cells 
with the presence of trichomes. The ground tissue composed of cortex, endodermis, pericycle and pith, outer cortex contains 3-5 layered polygonal parenchymatous cells and inner cortex contains 3-6 layered chlorenchymatous cells. Endodermis is a single layered, thin walled barrel shaped parenchymatous cells. Vascular bundles embedded in the ground tissues, present in two circle outer 6 and inner 3, open and bicollateral type. Parenchymatous oval or round shaped cells of bundle sheath present. 4-6 layered oval or irregular shaped Phloem cells are persent. Xylem 3- to 5- layered, the cells round or oval in shape, it is easily distinguished into proto and meta xylem. Pith is present in the centre.

In Lagenaria siceraria (Molina) Standl. the transverse section has oval wavy shaped outline and distinguished into dermal, ground and vascular tissue system, single layered epidermis made up of barrel shaped cells with the presence of trichomes. The ground tissue composed of cortex, endodermis, pericycle and pith, outer cortex contains 2-4 layered polygonal parenchymatous cells and inner cortex contains 4-6 layered collenchymatous cells. Endodermis is a single layered, thin walled barrel shaped parenchymatous cells. Vascular bundles embedded in the ground tissues, present in two circle five in each, open and bicollateral type. parenchymatous bundle sheath present. 4-6 layered oval or irregular shaped Phloem cells are persent. Xylem 3- to 5- layered, the cells round or oval in shape, it is easily distinguished into proto and meta xylem. Pith is present in the centre, it is discarded at maturity.

Figure 1. Transverse section of Stem

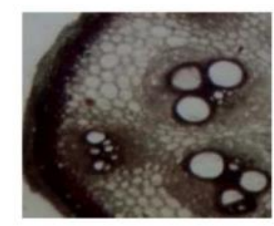

Coocinia grandis

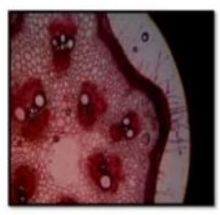

Lagenaria siceraria

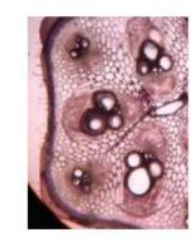

Luffa acutangula

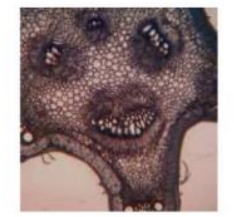

Cucurbita pepo

In Cucurbita pepo L. the transverse section has circular and wavy shaped outline and distinguished into dermal, ground and vascular tissue system, single layered epidermis made up of barrel shaped cells with the presence of trichomes. The ground tissue composed of cortex, endodermis, pericycle and pith, outer cortex contains 3-6 layered polygonal schlerenchymatous cells and inner cortex contains 5-8 layered collenchymatous cells. Endodermis is a single layered, thin walled barrel shaped parenchymatous cells. Vascular bundles embedded in the ground tissues, present in two circle, four in each circle, open and bicollateral type. parenchymatous bundle sheath present. 4-6 layered oval or irregular shaped Phloem cells are persent. Xylem 3- to 5- layered, the cells round or oval in shape, it is easily distinguished into proto and meta xylem. Pith is present in the centre.

The outer ring is composed of the often smaller bundles which are located at the angles of the stem. The inner ring contains the often larger bundles which alternate with those of the outer ring. However, in Cucurbita pepo the vascular bundles are arranged in one ring. The basic number of bundles is ten, each cycle consisting of five. Stem vascular bundles are bicollateral have also been observed [11]. The big size vascular bundle is vary from genus to genus. In Coccinia it is $21 \mu \mathrm{m}$ (vertical) and $18 \mu \mathrm{m}$ (horizondal), in Luffa it is $22 \mu \mathrm{m}$ (vertical) and $28 \mu \mathrm{m}$ (horizondal), in Langenaria it is $21 \mu \mathrm{m}$ (vertical) and $20 \mu \mathrm{m}$ (horizondal), the genus Cucurbita possesses the larger vascular bundles their size is genus the big vascular bundle size is $44 \mu \mathrm{m}$ (vertical) and $49 \mu \mathrm{m}$ (horizondal).

The vascular bundles of four species were bicollateral type. The vascular bundles of stem are organized into 6 to 10 bundles in four species, these characters were agreed with Metcalfe \& Chalk [12]. Like plant morphology, anatomical features are also great importance in taxonomy, since they are less affected by environmental factors. The anatomical differences observed in each specie must have been as a result of evolution, conferring heritable variation that could be exploited for taxanomic purposes. 


\section{CONCLUSION}

In conclusion, Anatomical features as revealed through microscropy in the present research can provide the information of similarities and differences of morphological and anatomical characteristics of the four species. It is hoped that the results of the present work will be useful in identification of family Cucurbitaceae.

\section{REFERENCE}

[1] Theingi, K and Yin, A. 2019. Morphological and anatomical characteristics of Coccinia grandis (1.) Voigt. and cucumis trigonus roxb. in mandalay region. J. Myanmar Acad. Arts Sci. (17) 4 pp. $733-750$.

[2] Aguoru C U and Ogaba J O. 2010. Ethonobotanical survey of anti-typhoid plants amongst the Idoma people of Nigeria. Int. Sci. Res. J. 2: 34-40.

[3] Ajuru M G and Okoli B E. 2013. The morphological characterization of the melon species in the Family Cucurbitaceae Juss. and their utilization in Nigeria. Inter J Modern Bot., 3(2): 15-19

[4] Immanuel Sagayaraj M and Nanditha V. 2019. Morpho-anatomical and histochemical studies on Coccinia grandis (L.) Voigt. (Cucurbitaceae). Journal of Pharmacognosy and Phytochemistry 2019; 8(3): 4296-4301

[5] Kochyan, A., Zhang, L.B., Schaefer, H. and Renner, S.S. 2007. A multilocus chloroplast for the cucurbitaceae and its implicatins for character evolution and classification. Mol. Phylogenetic. Evol. 44. 553 - 577.

[6] Ajuru M G and Okoli B E. 2013. The morphological characterization of the melon species in the Family Cucurbitaceae Juss. and their utilization in Nigeria. Inter J Modern Bot., 3(2): 15-19

[7] Ekeke C, Agogbua J and Okoli B E. 2015. Comparative anatomy of tendril and fruit stalk in Curcubitaceae Juss. from Nigeria. Int. J. Biol. Chem. Sci. 9(4): 1875-1887.

[8] Jeffrey C. 1990. An outline classification of the Cucurbitaceae. In: Bates DM, Robinson RW, Jeffrey C (Eds.), Biology and Utilization of the Cucurbitaceae. Cornell University Press Ithaca, NY. pp. 449-463.

[9] Aguoru, CU and Okoli BE. 2008. Seed coat anatomy of Momordica L. (Cucurbitaceae) in parts of tropical western Africa. Int. J. Trop. Agric. Food Syst. 2(1): 29-33.

[10] Aguoru, C.U. adn Okoli, B. E. 2012. Comparative stem and petiole anatomy of West African species of Momordica L (Cucurbitaceae). 6(15): 403 - 409.

[11] Mauseth, J.D., Plant Anatomy. Menlo Park: Benjamin Cummings, 1988, 568 p

[12] Metcalfe, C. R. and L. Chalk. (1957). Anatomy of the dicotyledons: leaves, stem and wood inrelation to taxonomy with notes on economic uses. Vol. II. Oxford University Press, Amen House, London.

Citation: Selvaraj, K, et.al (2020). "Stem Anatomy of Four Genera of Family Cucurbitaceae”. International Journal of Advanced Research in Botany (IJARB), 6(2), pp.15-18. DOI: https://doi.org/10.20431/24554316.0602002

Copyright: (C) 2020 Authors, This is an open-access article distributed under the terms of the Creative Commons Attribution License, which permits unrestricted use, distribution, and reproduction in any medium, provided the original author and source are credited. 